\title{
ANALISIS SWOT DAKWAH DI INDONESIA: Upaya Merumuskan Peta Dakwah
}

\author{
Abdullah \\ Fakultas Dakwah IAIN Sumatera Utara \\ Jl. Willem Iskandar Pasar V Medan Estate, 20371 \\ e-mail: abdullah_ariza@yahoo.com
}

\begin{abstract}
Abstrak: Islam merupakan agama dakwah yang menganjurkan pemeluknya untuk mengajak manusia supaya beriman dan berkarya serta menata kehidupan sesuai dengan nilai-nilai Islam. Pada tataran praktis, dakwah sebagai tugas mulia belum dikelola dengan profesional dan terukur. Pada sisi lain, dai belum mampu menjadi agen perubahan sebagaimana cita-cita Islam yaitu rahmat li al-'̂̂lamîn. Akibatnya posisi dakwah kurang diminati karena belum mampu memberikan pengaruh yang signifikan bagi kemajuan umat. Sebab itu, diperlukan pengkajian dan pemetaan secara komprehensif tentang kekuatan, kelemahan, peluang dan tantangan dakwah. Penulis berargumen bahwa pemetaan yang komprehensif terhadap hal tersebut dan kemudian diiringi dengan perencanaan dan pelaksanaan dakwah secara professional merupakan keniscayaan, sehingga pada gilirannya dakwah mampu menjadi solusi terhadap problem kehidupan umat di era globalisasi ini.
\end{abstract}

\begin{abstract}
A SWOT Analysis of Indonesia's Proselytization (da'wah), An Effort to Map Islamic Propagation in Indonesia. Islam is a religion of proselytization ( $d a^{i} w a h$ ), advocating its adherents to invite humankind to have faith and to put it in action and direct their lives in line with Islamic values. At the practical level, proselytization as a noble service has not been managed professionally and unmeasurable. Proselytizers (dai) have not managed to become agents of change as demanded by Islamic social mission. As a result, the position of a proselytizer is not in high demand because it has not managed to guide the Islamic community forward. Thus, a comprehensive research to map current effort of proselytization to find out its strengths, weaknesses, opportunities, and challenges is needed. This paper offer the argument that with a comprehensive map, along with professional planning and implementation, Islamic proselytization will provide solutions towards the variety of Islamic community problems in today's age of globalization.
\end{abstract}

Kata Kunci: dakwah, analisis SWOT, strategi pengembangan 


\section{Pendahuluan}

Islam sebagai agama wahyu, memiliki kebenaran yang mutlak pada sisi ajarannya. Kebenaran tersebut harus dikomunikasikan, disebarluaskan dan didemonstrasikan dalam kehidupan sosial, sehingga Islam menjadi nilai, sikap hidup dan perilaku sosial umat. Dakwah menduduki posisi sebagai upaya rekonstruksi masyarakat melalui kegiatan sosialisasi dan pelembagaan ajaran Islam secara lisan (bi al-lisân), tulisan (bi al-kitâbah) dan perbuatan (bi al-hâl). Kegiatan tersebut harus dilakukan secara berencana, sistematis, terprogram dan profesional. Untuk dapat melakukan hal itu secara tepat sasaran, maka perlu diadakan analisis dan pengkajian tentang ruang lingkup dan unsur-unsur dakwah secara komprehensif, sehingga kegiatan dakwah dapat berjalan secara terarah dan tercapai tujuan. Salah satunya melalui analisis SWOT. Berdasarkan analisis SWOT, kemudian perlu disusun dan diwujudkan menjadi peta dakwah. Hal itu kemudian menjadi dasar perencanaan dan pelaksanaan dakwah bagi dai dan organisasi dakwah.

SWOT adalah singkatan dari empat perkataan dalam bahasa Inggris, yaitu strengths (kekuatan), weaknesses (kelemahan), opportunities (peluang) dan threats (tantangan). Kekuatan adalah sumber daya, kapasitas, keunggulan dan potensi yang dapat digunakan secara efektif untuk mencapai tujuan. Kelemahan dipahami sebagai keterbatasan, kekurangan dan ketidakberdayaan yang dapat menghambat pencapaian tujuan. Sedangkan peluang merupakan situasi yang mendukung untuk pengembangan sesuai dengan tujuan yang hendak dicapai. Adapun ancaman adalah situasi yang tidak mendukung, berupa hambatan dan kendala atau berbagai unsur eksternal yang potensial yang mengganggu sehingga menimbulkan masalah, kerusakan atau kekeliruan. ${ }^{1}$

Analisis terhadap keempat hal tersebut, berarti mencoba melihat secara mendasar dan mendalam tentang kondisi objektif untuk kepentingan dan kemajuan dakwah, baik melihat ke dalam diri (intern) maupun kondisi di luar diri (ekstern). Dua hal yang disebutkan pertama, yaitu kekuatan dan kelemahan merupakan upaya analisis ke dalam, sedangkan peluang dan tantangan merupakan analisis ke luar. Untuk mencapai kemajuan dakwah, maka perlu menyelaraskan antara aktivitas dan kondisi internal dengan realitas ekternal agar dapat mencapai tujuan yang ditetapkan. Peluang-peluang pengembangan dakwah tidak akan berarti, jika tidak mampu memanfaatkan potensi, kekuatan dan sumber daya yang dimiliki pada tataran internal. ${ }^{2}$

Sesungguhnya untuk lebih akurat informasi dan data di lapangan menyangkut kekuatan, kelemahan, peluang dan tantangan dakwah, sejatinya perlu diadakan penelitian yang mendalam. Tetapi hal itu untuk ruang lingkup nasional, masih terlalu sulit. Karena itu, pembahasan ini mencoba memaparkan secara makro analisis SWOT dakwah Islam

${ }^{1}$ Musa Hubeis dan Mukhamad Najib, Manajemen Strategik dalam Pengembangan Daya Saing Organisasi (Jakarta: Elex Media Komputindo, 2008), h. 15-16.

${ }^{2}$ Ibid. 
di Indonesia, berdasarkan pengamatan, pemikiran dan analisis terhadap dakwah Islam dan perkembangannya di Tanah Air dewasa ini serta perkembangan global.

Melakukan analisis SWOT dakwah Islam di Indonesia adalah termasuk hal yang penting. Hal ini mengingat, dengan mengetahui kekuatan dan potensi yang dimiliki oleh umat Islam, khususnya yang berkaitan dengan dakwah, maka dapat memanfaatkan keunggulan, potensi dan kekuatan tersebut secara optimal serta pemberdayaannya. Tanpa memahami dan memberdayakan potensi yang ada, kegiatan dakwah menjadi lambat, karena kekuatan dan potensi tidak dimanfaatkan dan dikembangkan menjadi kondisi atau suasana kondusif. Demikian juga dengan memahami faktor kelemahan dakwah, tentunya akan menjadi bahan masukan (input) untuk melakukan upaya mengatasinya melalui berbagai strategi yang tepat. Kelemahan-kelemahan yang ada di tengah-tengah umat Islam, baik pada diri dai, organisasi dakwah maupun kelemahan umat secara keseluruhan, jika tidak diatasi, maka umat akan sulit untuk bangkit dan berkembang serta bersaing dalam kehidupan global yang semakin kopetitif.

Kedua hal di atas, sifatnya adalah mengungkapkan kondisi intern dakwah Islam. Selain itu dakwah juga harus dilihat dari segi peluang dan tantangannya. Peluang dan kondisi yang kondusif harus dimanfaatkan untuk kepentingan dakwah dan pengembangannya oleh para dai dan organisasi dakwah. Sebab, jika peluang dan kesempatan yang ada tidak dimanfaatkan dengan baik, maka dakwah Islam tidak akan berkembang secara menggembirakan, apalagi untuk bersaing dan menjadikan dakwah sebagai upaya pemecahan masalah umat yang sangat kompleks dewasa ini.

Jika peluang harus dimanfaatkan, maka tantangan-tantangan dakwah saat ini dan masa depan harus disingkirkan, diatasi dan dipecahkan atau setidak-tidaknya tantangan itu harus diperkecil dan diminimalisir. Untuk itu diperlukan pemahaman, pemikiran dan pengkajian yang komprehensif terhadap ruang lingkup dan unsur-unsur dakwah: dai, mad'uw, materi, metode, media dan tujuan, sehingga dapat dimunculkan konsep baru, solusi dan langkah-langkah operasional dalam menghadapi berbagai tantangan pada era globalisasi dan pascamodern saat ini. Di sinilah letak urgensi analisis SWOT, yaitu analisis tentang kekuatan, kelemahan, peluang dan tantangan untuk pengembangan dakwah dan kemudian perlu diwujudkan dalam peta dakwah.

Berdasarkan sensus 2010 penduduk Indonesia berjumlah 237.556.363 jiwa dan umat Islam berada pada posisi 87,21 persen, Katholik 1,83 persen, Protestan 6,04, Hindu 1,83 persen, Buddha 2,28 persen dan lain-lain 0,31 persen. ${ }^{3}$ Sementara rumah ibadah berjumlah 655.889, terdiri dari 589.454 masjid, 28.486 gereja Protestan, 13.076 gereja Khatolik, 21.121 pura Hindu dan 3.752 vihara Buddha. ${ }^{4}$ Selain itu, kini pemerintah juga

${ }^{3}$ Badan Pusat Statistik, Penduduk Indonesia 2010, h. 11.

${ }^{4}$ Tarmizi Taher, Menuju Ummatan Wasathan (Jakarta: PPIM-IAIN, 1998), h. 29. 
telah mengakui keberadaan agama Konghucu, namun data keagamaannya belum dapat diakses secara luas.

Dari segi pemahaman keagamaan di kalangan umat Islam terbagi dua yaitu bersifat tradisional dan modernis. Paham Islam tradisional diwakili oleh kalangan Nahdlatul Ulama (NU), Al Jam'iyatul Washliyah, Al Ittihadiyah dan Mathla'ul Anwar. Sementara paham Islam modernis diwakili oleh Muhammadiyah dan Persatuan Islam. ${ }^{5}$ Dari segi pengamalan keagamaan dari waktu ke waktu mengalami peningkatan, khususnya dalam hal melaksanakan ibadah haji.

Pada sisi lain, sejak era reformasi terjadi penguatan dan peningkatan gerakan Islam struktural dan kultural. Tipikal pertama ditandai dengan maraknya pendirian partai-partai Islam, meskipun belum mampu memainkan peranan yang signifikan. Tipikal kedua ditandai dengan menjamurnya sejumlah gerakan Islam, yang disebutkan radikal seperti Front Pembela Islam (FPI), Laskar Jihad, Majelis Mujahidin dan Hizbut Tahrir Indonesia (HTI). ${ }^{6}$ Indonesia yang masa Orde Baru diwarnai oleh Islam moderat, Islam kultural dan Islam inklusif, sekarang ikut diwarnai oleh gerakan Islam politik dan Islam radikal. Gerakan Islam struktural dan kultural di era reformasi telah membawa perubahan politik di Indonesia. Islam kembali menjadi faktor penting dalam perubahan politik nasional. Gerakan ini memiliki komitmen yang tinggi terhadap Islam dan daya jelajah yang cukup besar di masyarakat.

\section{Analisis Kekuatan Dakwah}

Letak kekuatan dakwah Islam secara umum dapat dilihat dari tiga sudut pandang, yaitu dari segi konsep dakwah, potensi umat dan peranan organisasi dakwah. Pertama, dilihat dari segi konsep. Dakwah merupakan watak yang inheren dari ajaran Islam, yaitu antara Islam dengan dakwah tidak dapat dipisahkan. Lebih tegas Sayyid Quthb (w. 1966) mengatakan bahwa Islam adalah agama dakwah, ${ }^{7}$ yaitu agama yang mewajibkan setiap Muslim untuk mengajak dan menyampaikan kebenaran yang datangnya dari Allah SWT, supaya nilai rahmat Islam dapat bersemi dan tumbuh dalam kehidupan individu (syakhshiyah), keluarga (usrah), masyarakat dan negara (daulah). Dakwah juga merupakan sifat nubuwwah, yaitu sifat para Nabi dan Rasul sebagai manusia pilihan yang diutus oleh Allah SWT. untuk mengajak manusia kepada kebenaran ajaran yang dibawanya (QS. al-

${ }^{5}$ Deliar Noor, "Kata Pengantar," dalam Khamami Zada, Islam Radikal (Jakarta: Teraju, 2002), h. xiv.

${ }^{6}$ Khamami Zada, Islam Radikal (Jakarta: Teraju, 2002), h. 4.

${ }^{7}$ Sayyid Quthb, Fî Zhilâl al-Qur'ân, Vol. I (Beirut: Dâr al-Syurûq, 1986), h. 129. Lihat, Ismail R. al-Faruqi dan Lois Lamya al-Faruqi, Atlas Budaya: Menjelajah Khazanah Peradaban Gemilang, terj. Ilyas Hasan (Bandung: Mizan, t.t.), h. 220; A. Mukti Ali, Beberapa Persoalan Agama Dewasa Ini (Jakarta: Rajawali Pers, 1987), h. 71. Selain Islam, agama Buddha dan Kristen juga disebut sebagai agama dakwah. Lihat misalnya Thomas W. Arnold, the Preaching of Islam, terj. A. Nawawi Rambe (Jakarta: Wijaya, 1985), h. 1. 
Ahzâb/33: 45-46). Kemudian tugas tersebut dilanjutkan oleh para pengikut Rasul dan hal ini juga terlihat dalam sejarah dakwah Islam. Tersebarnya Islam ke seluruh penjuru dunia, termasuk ke Indonesia oleh para saudagar, menjadi bukti bahwa pemahaman dakwah dan semangat memperjuangkan kebenaran telah terpatri dalam setiap gerak langkah Muslim, apapun profesinya. ${ }^{8} \mathrm{Hal}$ ini merupakan kekuatan dakwah dilihat dari segi konsep.

Selanjutnya, menurut M. Natsir (w. 1993), dakwah dalam makna yang luas adalah kewajiban yang harus dipikul oleh setiap Muslim yang mukalaf dan tidak bisa seorang pun menghindar dari kewajiban tersebut. ${ }^{9}$ Menurutnya, dakwah yang bertumpu pada al-amr bi al-ma'rûf wa al-nahyi 'an al-munkar merupakan syarat mutlak bagi kesempurnaan dan keselamatan hidup manusia. Ditegaskan bahwa kewajiban sebagai pembawa fitrah manusia yang selalu cenderung kepada kebenaran, di samping manusia juga sebagai makhluk yang bermasyarakat. Jika dakwah berhenti, maka kemungkaran akan merajalela.

Tugas berdakwah tidak hanya menjadi tanggung jawab ulama, dai dan khatib, melainkan tugas setiap pribadi Muslim sesuai dengan kemampuan, keahlian dan profesi masing-masing. ${ }^{10}$ Ulama berdakwah dengan ilmu yang mereka miliki, baik bi al-lisân maupun bi al-kitâbah. Penguasa atau pemerintah berdakwah dengan kekuasaan dan jabatan yang disebutkan dengan dakwah struktural. Sementara para hartawan (aghniyâ') berdakwah dengan harta yang mereka miliki, yaitu dakwah bi al-hâal. Di samping itu, bagi orang yang tidak memiliki ilmu pengetahuan, kekuasaan dan harta, juga dituntut untuk membenci setiap kemungkaran dan ia sendiri harus menjauhi kemungkaran tersebut.

Dalam konteks dakwah sebagai upaya perubahan, khususnya merubah kemungkaran, Nabi Muhammad SAW. telah memberikan uraian tugas berdasarkan keahlian, jabatan dan kedudukan seorang Muslim. Hal itu berdasarkan Hadis berikut:

"Barang siapa di antara kamu melihat kemungkaran maka hendaklah mengubahnya dengan tangannya, jika tidak bisa, maka hendaklah dengan lisannya, jika tidak bisa maka dengan hatinya, dan yang demikian itu adalah selemah-lemahnya iman".

Pemahaman terhadap konsep dakwah seperti dipaparkan di atas, kemudian diiringi dengan bentuk operasional di tengah-tengah kehidupan masyarakat, maka hal ini benarbenar akan menjadi suatu kekuatan bagi dakwah Islam. Apalagi realisasinya dilaksanakan secara kelompok yang diorganisir oleh organisasi atau lembaga dakwah maupun kegiatan dakwah yang dilaksanakan oleh person dai dalam makna yang luas.

\footnotetext{
${ }^{8}$ Hamka, Sejarah Umat Islam (Singapura: Pustaka Nasional, 2005), h. 681-682.

${ }^{9}$ M. Natsir, Fiqhud Dakwah (Jakarta: Media Dakwah, t.t.), h. 110.

${ }^{10}$ Ibid., 111.

${ }^{11}$ Muslîm bin Hajjâj, Shahîh al-Muslîm, Vol. I, Bab Îmân. No. 78. h. 45-46.
} 
Pada sisi lain, dakwah Islam tidak hanya terbatas pada kegiatan dakwah yang dilakukan oleh lembaga dakwah dan dai terhadap jamaah atau umat yang disebut dakwah jamaah. Tetapi juga dikenal dengan konsep dakwah fardiyah, yaitu dakwah yang dilakukan oleh dai terhadap satu orang atau beberapa orang mad'uw secara tidak formal. Dakwah fardiyah mempunyai beberapa keunggulan dan keistimewaan dibandingkan dakwah jamaah. ${ }^{12}$ Dakwah fardiyah dalam operasionalnya dapat berlangsung di mana saja, kapan saja dan dengan siapa saja mad'uw-nya, karena tidak terikat dengan acara protokoler seperti telah dibahas sebelum ini. Karena itu, jika dakwah dipahami dalam arti luas dan menjadi gerakan bersama di kalangan umat Islam, maka ini akan menjadi suatu kekuatan untuk perubahan sosial sesuai dengan cita-cita al-Qur'an, agar komunitas Muslim menjadi umat terbaik (khair ummah).

Kedua, kekuatan dakwah dilihat dari segi kuantitas dan kualitas serta potensi umat Islam di Indonesia. Mayoritas penduduk Indonesia, yaitu $87 \%$ adalah beragama Islam, bahkan bangsa Indonesia merupakan pemeluk agama Islam terbesar di muka bumi. ${ }^{13}$ Kondisi ini pada suatu sisi merupakan kekuatan bagi dakwah Islam, apabila potensi, kualitas dan partisipasi umat yang mayoritas ini dapat digerakkan, dan dimanfaatkan untuk kepentingan dakwah Islam. Potensi elit politik, elit ekonomi dan elit pendidikan pada setiap level masyarakat perlu pemberdayaan. Sebaliknya, jumlah yang mayoritas ini, dapat juga menjadi bumerang, bila tidak dibarengi dengan kualitas yang memadai.

Elit politik dan penguasa dari kalangan umat Islam harus diajak, didorong dan diminta untuk ikut membantu dan bertanggung jawab terhadap kemajuan dakwah. Sesungguhnya, eksistensi elit politik dan penguasa dapat mengubah masyarakat lebih cepat. Keberadaannya harus memainkan peranan penting, seperti melahirkan undangundang atau peraturan yang dapat memproteksi umat. Menurut Moh Ali Aziz, hasil dari dukungan politik telah berkembang ekonomi syariah dan penerapan syariah Islam di beberapa daerah di tanah air. Namun, dakwah politik terkadang tidak membawa kedamaian dan ketenteraman di kalangan mitra dakwah. ${ }^{14}$ Untuk masa depan masih perlu ditingkatkan dakwah melalui jalur politik, karena masih banyak hak-hak umat Islam yang perlu diperjuangankan, seperti undang-undang halal yang sudah 16 tahun belum disahkan, padahal Indonesia merupakan negeri yang mayoritas penduduk beragama Islam. Sementara negeri yang minoritas umat Islam seperti Singapura telah memiliki undang-undang tersebut.

Dakwah Islam akan menjadi kuat, jika umat yang mayoritas ikut mendukung dan membantu aktivitas dakwah sesuai dengan kemampuan dan profesi masing-masing. Karena itu, organisasi dakwah dan dai tidak memandang mereka sebagai objek atau sasaran

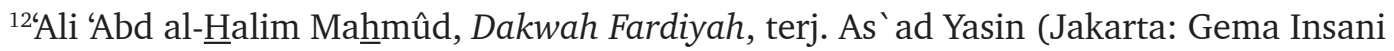
Press. 1995), h. 30.

${ }^{13}$ Nurcholish Madjid, Islam Doktrin dan Peradaban (Jakarta: Yayasan Wakaf Paramadina, 1992), h. 160.

${ }^{14}$ Moh Ali Aziz, Ilmu Dakwah (Jakarta: Kencana Prenada Media Group, 2004), h. 5. 
dakwah semata, tetapi mereka harus diposisikan sebagai mitra dakwah dan dipersiapkan, diberdayakan dan didorong untuk menjadi subjek dakwah atau dai. Proses dan kegiatan disebut merupakan strategi pengembangan dakwah. Jika mereka belum dapat diharapkan tampil sebagai subjek dakwah, maka sekurang-kurangnya partisipasi dan dukungan terhadap aktivitas dakwah. Terwujud atau tidaknya hal ini sangat tergantung kepada kemampuan organisasi dakwah dan dai sebagai unsur terpenting dalam sistem dakwah untuk meningkatkan sumber daya umat.

Ketiga, kekuatan dakwah dilihat dari segi keberadaan organisasi keagamaan di Indonesia yang bergerak dalam bidang dakwah. Kekuatan dakwah terletak pada peran aktif organisasi keagamaan atau organisasi Islam di Indonesia, yang ikut mengemban dakwah. Tidak ada satu pun organisasi keagamaan yang tidak ikut berkiprah dalam bidang dakwah. Karena dakwah dalam terminologi yang luas meliputi bidang politik, ekonomi, usaha-usaha sosial, kegiatan ilmu dan teknologi, kreasi seni, dan kodifikasi hukum. Hal itu bagi seorang Muslim harus menjadi alat dakwah. ${ }^{15}$

Organisasi keagamaan Islam lebih tua usianya dari negeri ini, karena sudah ada sebelum Indonesia merdeka. Organisasi keagamaan yang terbesar saat ini adalah Muhammadiyah (1912), Nahdlatul Ulama (1926) dan Al-Washliyah (1930). Selain itu, terdapat organisasi lainnya seperti Mathla'ul Anwar, Ittihadul Muballighin, dan Al Irsyad. Muhammadiyah misalnya mengatakan bahwa masalah dakwah merupakan hal yang sangat pokok. Karena maksud dan tujuan pendirian persyarikatan tersebut ialah untuk menegakkan dan menjunjung tinggi agama Islam sehingga terwujud masyarakat Islam yang sebenar-benarnya. ${ }^{16}$

Khusus di kalangan cendikiawan, terdapat Ikatan Cendekiawan Muslim Indonesia (ICMI) yang lahir pada tahun 1990. Sedangkan di kalangan mahasiswa dikenal beberapa organisasi yang menamakan diri sebagai organisasi Islam, seperti Himpunan Mahasiswa Islam (1947), ${ }^{17}$ Himpunan Mahasiswa Al Washliyah (1959), Ikatan Mahasiswa Muhammadiyah (1964), dan Pergerakan Mahasiswa Islam Indonesia (1964).

Organisasi yang menamakan diri dan mengkhususkan diri pada kegiatan dakwah adalah Dewan Dakwah Islamiyah Indonesia (1967) dan Majelis Dakwah Islam (MDI). Organisasi yang disebutkan terakhir merupakan organisasi di bawah pembinaan Partai Golongan Karya (GOLKAR).

Sementara partai politik yang masih eksis saat ini yang menyatakan diri sebagai partai Islam adalah Partai Persatuan Pembangunan (PPP), Partai Bulan Bintang (PBB) ${ }^{18}$

${ }^{15}$ M. Amien Rais, Cakrawala Islam (Bandung: Mizan, 1991), h. 27.

${ }^{16}$ Syarifuddin Jurdi, 1 Abad Muihammadiyah (Jakarta: Kompas Media Nusantara, t.t.), h. 258.

${ }^{17}$ Azhari Akmal Tarigan, Jalan Ketiga Pemikiran Islam HMI (Bandung: Citapustaka Media Perintis, 2008), h. 65.

${ }^{18}$ Sahal L. Hasan, et al., (ed.), Memilih Partai Islam (Jakarta: Gema Insani Press, 1998), h. 23. 
Partai Kebangkitan Bangsa (PKB) ${ }^{19}$ dan Partai Keadilan Sejahtera (PKS) ${ }^{20}$ Salah satu tujuan kehadiran partai adalah menjadi wahana untuk masuk ke dalam struktur kekuasaan politik untuk kepentingan dakwah struktural. ${ }^{21}$ Partai tersebut tidak hanya menyebutkan diri sebagai partai Islam, melainkan juga menyebutkan diri secara khusus sebagai partai dakwah, melalui kegiatan amar ma'rûf nahi munkar, seperti pengakuan PKS. ${ }^{22}$

Semua organisasi dan partai yang disebutkan di atas dan organisasi Islam lainnya, baik yang bersifat nasional maupun kedaerahan, kehadirannya adalah cukup penting, karena mempunyai visi dan misi yang sama, yaitu sama-sama untuk memajukan kehidupan umat beragama di Tanah Air. Terlepas dari kelemahan masing-masing, bahwa tidak dapat dipungkiri, peran organisasi-organisasi tersebut cukup besar dalam pembinaan kualitas keberagamaan di kalangan umat Islam. Setiap organisasi telah berperan sesuai dengan program dan skala prioritas, yang merupakan refleksi dari tujuan berdirinya organisasi tersebut. Dakwah yang bersifat multi dimensional dan integratif, tentunya akan menjadi kuat dan lebih mampu memecahkan masalah-masalah aktual dan strategis di kalangan umat. Hal yang sangat diperlukan adalah terjalinnya kerjasama yang baik di antara organisasi tersebut. Kemudian, jika terjadi semacam kompetisi, tentunya dalam rangka fastabiq al-khairât. Namun sikap yang diperlukan dari dai dan organisasi dakwah tidak sekedar reaktif melainkan sikap proaktif, atau tidak sekedar mengkritik, tetapi juga mengusulkan bahkan menawarkan program alternatif untuk kemajuan umat.

\section{Analisis Kelemahan Dakwah}

Merupakan suatu fakta yang tidak terbantahkan bahwa Islam telah mampu bertahan berabad-abad di Nusantara ini, dengan segala kekuatan dan kelemahannya. Umat Islam sebagai penduduk mayoritas dari waktu ke waktu tidak banyak mengalami perubahan. Ini artinya daya tahan agama Islam dalam pergumulan dengan berbagai tantangan sungguh luar biasa. Namun pada sisi lain, masih cukup banyak ditemukan kelemahan di kalangan umat Islam dalam konteks dakwah. Hal yang delematis adalah bahwa umat Islam sebagai penduduk mayoritas di Indonesia, namun minus kualitas. Menurut Ahmad Syafii Maarif, tiga hal utama kelemahan dan ketertinggalan umat, yaitu kemiskinan, kebodohan dan keterbelakangan. ${ }^{23}$ Label mayoritas dengan minus kualitas, hal ini akan memperburuk citra Islam, sekaligus citra Indonesia di mata dunia, jika tidak segera diatasi melalui pendekatan multi demensional dan integratif.

${ }^{19}$ Ibid., h. 24.

${ }^{20}$ Ibid., h. 32

${ }^{21}$ Ibid., h. 21.

${ }^{22}$ Ibid., h. 59.

${ }^{23}$ Ahmad Syafi'i Maarif, Islam dalam Bingkai Keindonesiaan dan Kemanusiaan: Sebuah Refleksi Sejarah (Bandung: Mizan, 2009), h. 243. 
Dakwah pada tataran internal merupakan perwujudan dari berbagai kelemahan di kalangan umat Islam. Karena itu, perlu diidentifikasi agar dapat diperbaiki ke depan untuk kemajuan umat dan kejayaan peradaban Islam. Tantangan internal juga dapat direkayasa oleh pihak eksternal agar umat Islam menjadi lemah dan tidak berdaya. Dalam konteks tantangan dakwah, Hamka melihat bahwa umat Islam memiliki empat penyakit utama yaitu keimanan yang lemah, egois, mabuk kekuasaan dan nafsu yang tidak terkendali. ${ }^{24}$ Pertama, lemahnya semangat untuk berkorban untuk kepentingan agama. Hal ini secara tidak langsung juga menunjukkan lemahnya iman di kalangan umat Islam. Menurut Hamka, iman yang lemah adalah suatu kehinaan, yang bisa mendorong kepada akhlak yang tidak baik, takut kepada musuh atau pengecut dan mementingkan diri sendiri. Setiap umat Islam seharusnya memiliki jati diri sebagaimana yang digambarkan dalam Q.S. al-Fath/48: 29, yaitu tegas terhadap orang kafir dan berkasih sayang sesama Muslim. ${ }^{25}$ Kedua, mementingkan diri sendiri dan tidak peduli terhadap hak-hak orang lain seperti hak sahabat dan tetangga. Ketiga, mabuk kekuasaan. Keempat, nafsu yang tidak terkendali. Selain melihat banyaknya kelemahan umat Islam, Hamka juga menasehati dai agar tidak membangkitkan isu khilafiah, karena hal itu dapat membawa kepada perpecahan di kalangan umat Islam. Di samping itu, perlu dikembangkan sikap optimisme dalam mencapai kesuksesan Islam. Sikap seperti ini dapat dikembangkan dengan adanya keyakinan bahwa al-Qur'an memiliki konsep yang sempurna. ${ }^{26}$

Kemudian M. Natsir juga melihat beberapa kelemahan umat Islam. Pertama, umat Islam merupakan penduduk mayoritas di Indonesia, namun potensi atau sumber daya manusia (SDM) yang dimiliki masih rendah. Begitu juga dengan pemahaman tentang Islam. Menurut M. Natsir, pemahaman terhadap Islam dipengaruhi oleh persepsi Barat. Selain itu, masih terdapat pemahaman sempit yang menyelubungi umat Islam, yang mendorong adanya dikotomi, sikap ekstremis, mempertentangkan Islam dengan Pancasila sebagai dasar negara dan berbagai sikap lainnya yang tidak kondusif untuk kemajuan Islam. Selain itu, beberapa politisi Muslim berpaham sekuler, dan mereka tidak ikut bertanggung jawab terhadap kemajuan Islam. ${ }^{27}$

Kedua, masalah kemunduran umat Islam dalam bidang pendidikan, ekonomi maupun kesehatan. Tentang peran dan kehidupan ekonomi umat Islam, M. Natsir mengatakan "Di jalur ekonomi, jelas amat menyolok. Dulu umat Islam setidaknya memiliki asset di bidang pembangunan ekonomi. Kelas menengah ekonomi di masa lalu umumnya adalah dari kalangan umat. Namun perkembangan yang ada menunjukkan bahwa seolah umat "terlempar" dari percaturan ekonomi nasional." 28

\footnotetext{
${ }^{24}$ Hamka, Prinsip dan Kebijaksanaan Dakwah, h. 25 dan 29.

${ }^{25} \mathrm{Ibid}$, h. 26.

${ }^{26} \mathrm{Ibid}, \mathrm{h} .28$.

${ }^{27}$ Natsir, Fiqhud Dakwah, h. 60.

${ }^{28}$ Ibid, h. 28-29.
} 
Ketiga, kelemahan dalam pengelolaan potensi umat Islam. Hakikatnya, potensi umat Islam terus meningkat dari waktu ke waktu. Tetapi potensi yang ada tidak terurus dan dimanfaatkan secara optimal untuk kepentingan Islam. Padahal dalam peningkatan dakwah sangat dibutuhkan peran dan kerjasama umat Islam dalam berbagai bidang. Selain itu, menurut M. Natsir, sebagian umat Islam bersikap mengalah, tidak berani mengambil risiko dan tidak waspada terhadap tindak-tanduk pihak eksternal. Sikap ini, menurut tokoh lawan polemik Soekarno ini, muncul karena penyakit cinta kepada dunia (hubb al-dunya) yang berlebihan, meskipun hal itu bertentangan dengan hati nuraninya. Menurutnya kondisi ini sangat berbeda dengan sikap masyarakat pada zaman pra dan pasca kemerdekaan. Penyakit cinta dunia yang berlebihan, juga dipengaruhi oleh kemajuan ilmu pengetahuan dan teknologi serta dampak modernisasi.

Keempat, kelemahan dalam bidang memajukan generasi Islam untuk estafet kepemimpinan. Menurut M. Natsir, hal ini karena sikap tidak peduli antara generasi tua kepada generasi muda. Akibatnya terjadi kelumpuhan dan kelemahan yang mempengaruhi kelanjutan kepemimpinan masa depan. Untuk mengatasi kondisi ini, Natsir menyarankan agar generasi muda Islam, melalui organisasi atau lembaga dakwah mengadakan pertemuan untuk mengkaji masalah tersebut secara serius, menganalisis situasi dan mengembangkan persamaan persepsi. Tetapi karena hal ini termasuk persoalan yang sensitive, maka harus berhati-hati dan tidak terlalu digembar-gemborkan. ${ }^{29}$

Pada sisi lain, kelemahan dakwah terletak pada dai dan organisasi dakwah dalam pengelolaannya. Keberadaan dai dan organisasi dakwah dapat dipandang sebagai kekuatan, namun pada sisi lain dewasa ini masih ditemukan berbagai kelemahan. Kelemahan tersebut antara lain seperti belum adanya kerjasama yang menggembirakan antar organisasi dakwah, kompetensi dai belum memadai, kegiatan dakwah belum menyentuh semua aspek kehidupan umat, peta dakwah belum jelas, lemahnya manajemen dakwah yang merupakan gambaran belum profesional penanganan kegiatan dakwah, dan persoalan sumber dana dakwah yang belum jelas dan sederet kelemahan lainnya dapat diurutkan. Pembahasan berikut ini mencoba menganalisa empat kelemahan yang dianggap sangat mendasar.

Pertama, kerjasama antar organisasi dakwah dipandang cukup penting bagi upaya mengatasi kelemahan baik pada tataran konsep maupun pada tataran operasional dakwah. Karena dengan terwujudnya kerjasama yang baik, maka lebih memungkinkan untuk saling memahami, saling belajar dan saling membantu, serta menghindari tumpang tindih

${ }^{29} \mathrm{Ibid}$., h. 69. Pada tahun 1985, pemerintah Indonesia mengeluarkan Undang-undang nomor 5 tahun 1985, tentang Pancasila sebagai asas tunggal dalam berorganisasi. Undang-undang tersebut terdapat pro dan kontra di kalangan umat Islam. Akibatnya organisasi Islam dan aktivitas dakwah mendapat pengawalan dari pemerintah. Karena itu, M. Natsir menasehatkan agar umat Islam berhati-hati dalam bertindak. Lihat Abdul Aziz Thaba, Islam dan Negara dalam Politik Orde Baru (Jakarta: Gema Insani Press, 1996),h. 265. 
(over lapping) kegiatan dakwah terhadap objek yang sama. Untuk tahap awal misalnya dilakukan pertemuan antara pimpinan organisasi (top leader).

Kedua, kelemahan dakwah terletak pada tenaga dai yang berkaitan dengan kualitas, profesionalisme dan kompetensi. ${ }^{30}$ Dai merupakan unsur pertama dan utama dalam proses kegiatan dakwah. Karena itu keberadaannya sangat menentukan baik dalam perencanaan, pelaksanaan maupun dalam pencapaian tujuan dakwah. Mengingat hal itu, maka pada setiap saat sangat dibutuhkan dai yang berkualitas dan profesional serta mampu memberikan alternatif jawaban terhadap permasalahan yang dihadapi oleh umat di era globalisasi saat ini.

Ketiga, kegiatan dakwah belum menyentuh berbagai aspek dalam kehidupan masyarakat. Potret dakwah selama ini, lebih dominan dalam bentuk lisan seperti khutbah, ceramah dan sejenisnya. Tema-tema yang dibicarakan pun masih berfokus pada masalah akidah dan ibadah serta berkutat sekitar masalah halal dan haram, surga dan neraka, sementara aspek keislaman lainnya yang sangat luas sering terabaikan. Dakwah dalam terminologi modern adalah upaya rekonstruksi masyarakat yang meliputi perbaikan kehidupan dalam bidang kesejahteraan sosial, pendidikan, hukum, politik, ekonomi, kehidupan budaya, pengembangan ilmu pengetahuan dan teknologi serta mental spiritual. ${ }^{31}$ Sebab itu, tema-tema dakwah harus lebih beragam sesuai dengan permasalahan dan tuntutan kehidupan umat.

Keempat, peta dakwah yang belum jelas. Bila diperhatikan keragaman permasalahan kehidupan umat, maka kegiatan dakwah bukan kegiatan sambil lalu atau sekali gebrakan lantas membuahkan hasil. Tetapi kegiatan dakwah memerlukan penanganan dan manajemen yang baik serta perencanaan dakwah yang didasarkan pada kondisi objektif umat. Kemudian persoalan selanjutnya adalah bagaimana merumuskan strategi kebijakan dakwah berdasarkan perencanaan yang didasarkan pada hasil penelitian dakwah dan kemudian dituangkan dalam peta dakwah.

Pada sisi lain, titik lemah umat Islam pada aspek politik. Faktanya bahwa umat Islam mayoritas dalam sensus, minoritas dalam peran dan kualitas. Jadi jika kecerdasan politik merupakan salah satu titik lemah umat, maka dakwah seharusnya diorientasikan pada upaya mencerdaskan politik umat. Ada persoalan yang mendasar yang perlu diluruskan bahwa secara visi, politik belum disepakati sebagai instrumen yang merupakan bagian

\footnotetext{
${ }^{30}$ Kompetensi da'i dibedakan kepada tiga hal, yaitu kompetensi substantif, kompetensi metodologis dan kompetensi teknis. Kompetensi subtansif terkait dengan penguasaan ilmu keislamam yang luas dan mendalam dan berakhlak mulia. Kompetensi metodologis menekankan pada kemampuan da'i dalam merencanakan dan melaksanakan dakwah sesuai dengan kondisi objektif sasaran dakwah. Sementara kompetensi teknis merupakan kemampuan menguasai teknologi yang mendukung keberhasilan dakwah. Lihat Abdullah, Wawasan Dakwah: Kajian Epistemologi, Konsepsi dan Aplikasi Dakwah (Medan: IAIN Press, 2002), h. 45.

${ }^{31}$ Sukrianto, et al., Pergumulan Pemikiran dalam Muhammadiyah (Yogyakarta: Sipress, 1990), h. 127.
} 
integral dari dakwah dan amar makruf nahi mungkar. Menurut Eep Saefulloh Fatah terdapat 25 jenis kekeliruan dalam memahami dan praktik politik kalangan umat, di antaranya gegap gempita di wilayah ritual, senyap di wilayah politik dan melihat politik sebagai hitam putih. ${ }^{32}$

\section{Analisis Peluang Dakwah}

Secara umum ada dua hal yang menjadi peluang bagi pelaksanaan dakwah Islam di Indonesia. Pertama; keberadaan Pancasila dan Undang-Undang Dasar 1945 (UUD 1945), yang memberikan peluang bagi pemeluk agama, termasuk Islam untuk meyakini, beribadah dan mengembangkan agamanya masing-masing. Kedua, peluang akibat dari kemajuan ilmu pengetahuan dan teknologi (IPTEK), terutama kemajuan dalam bidang teknologi komunikasi dan media massa, baik media cetak maupun media elektronik.

Ketika Soeharto masih sebagai presiden, dalam berbagai kesempatan sering dikatakan, bahwa Indonesia adalah negara yang berdasarkan Pancasila, bukan negara sekuler dan bukan pula negara agama (teokrasi). Meskipun Indonesia bukan negara agama, namun masalah agama dipandang sebagai salah satu hak yang paling asasi di antara hak-hak asasi manusia.

Hal tersebut terlihat dari asas pembangunan nasional, bahwa asas pertama adalah keimanan dan ketakwaan terhadap Tuhan Yang Maha Esa. Ini dimaksudkan bahwa segala usaha dan kegiatan pembangunan nasional dijiwai, digerakkan dan dikendalikan oleh keimanan dan ketakwaan terhadap Tuhan Yang Maha Esa sebagai nilai luhur yang menjadi landasan spiritual, moral dan etik dalam rangka pembangunan nasional sebagai pengamalan Pancasila.

Hal di atas menunjukkan bahwa cukup penting keberadaan iman dan takwa Terhadap Tuhan Yang Maha Esa bagi pembangunan nasional. Untuk meningkatkan kedua hal itu, maka diantaranya melalui kegiatan dakwah. Secara implisit Pancasila dan UUD 1945 memberikan kesempatan dan peluang bagi kegiatan dakwah dan hasil kegiatan dakwah juga akan memberikan dampak yang positif bagi pembangunan nasional.

Sungguhpun demikian, pemerintah melalui Kementerian Agama selalu memantau, mengawasi dan memberikan bimbingan tentang penyiaran agama, agar tidak terjadi benturan-benturan di antara agama yang ada di Indonesia dan demi terciptanya Trilogi Kerukunan Umat Beragama. Secara lebih tegas lagi Menteri Agama telah mengeluarkan Keputusan tentang Pedoman Penyiaran Agama. Salah satu yang sangat ditekankan adalah bahwa penyiaran agama tidak dibenarkan untuk ditujukan kepada orang yang telah memeluk sesuatu agama. ${ }^{33}$

${ }^{32}$ Eep Saefulloh Fatah, "Kalangan Islam: dari Statistik ke Politik?," dalam Dhurorudin Mashad (ed.), Akar Konflik Politik Islam di Indonesia (Jakarta: Pustaka Al-Kautsar, 2008), h. xiv.

${ }^{33}$ Anwar Masy'ari, Butir-Butir Problematika Dakwah (Surabaya: Bina Ilmu, 1993), h. 155. 
Sebagaimana disebutkan di atas bahwa dengan kemajuan ilmu pengetahuan dan teknologi (IPTEK) pada satu sisi dapat menjadi peluang dakwah. Namun pada sisi lain, kemajuan IPTEK dapat memberikan dampak negatif atau menjadi tantangan dakwah. Di sinilah fungsi dakwah dan tugas dai untuk menggiring umat agar dapat mengoptimalkan nilai "rahmat" dari kemajuan IPTEK dan menekan atau menghindari nilai "laknat" dan dampak negatif seperti kehadiran situs-situs porno di internet.

Secara lebih khusus, kehadiran media massa baik media cetak maupun media elektronik adalah konsekuensi logis dari kemajuan ilmu pengetahuan dan teknologi. Menurut Ibnu Hammad, kemajuan teknologi komunikasi dan informasi (Information and Communication Technology-ICT), khususnya telepon, komputer dan satelit yang membentuk jaringan komunikasi di alam maya (cyber), kini informasi sudah mengejawantah dalam segala bentuk (omniform), berada dimana-mana (omniplace) dan untuk berbagai keperluan (omnipurpose). ${ }^{34}$ Keberadaannya menawarkan peluang bagi kegiatan dakwah atau setidak-tidaknya melalui media massa pesan-pesan dakwah (massage) dapat menjangkau lapisan masyarakat yang lebih luas, misalnya melalui koran, radio, televisi dan internet.

Untuk itu, umat Islam, khususnya pengelola lembaga dakwah dan dai harus terampil memanfaatkan media-media tersebut. Usaha ke depan, apakah bersifat akademik, kultural atau politis, harus memperhitungkan perkembangan media audio visual dan teknologi komunikasi mutakhir.

\section{Analisis Tantangan Dakwah}

Dewasa ini, tantangan dakwah tampaknya semakin berat, terutama tantangan akibat dari kemajuan ilmu pengetahuan dan teknologi serta dampak dari arus modernisasi dan globalisasi. Walaupun di balik tantangan tersebut sesunggunya juga menawarkan peluang-peluang yang harus dimanfaatkan. Tantangan dakwah dapat dibedakan kepada dua hal. Pertama, tantangan yang merupakan ekses atau dampak dari kemajuan ilmu pengetahuan dan teknologi dan sisi buruk dari globalisasi. Kedua, tantangan yang berasal dari pihak non-Muslim, baik yang berasal dari dalam negeri maupun luar negeri, berbagai program dan strategi yang mereka lakukan. Ketiga, tantangan dakwah akibat dari berbagai persoalan kebangsaan yang memberikan efek negatif kepada kegiatan dakwah.

Sementara pada sisi lain, dakwah juga dihadapkan dengan persoalan kemiskinan, terutama dampak dari krisis ekonomi, yang telah mengakibatkan penduduk Indonesia berada di bawah garis kemiskinan. Selain itu tantangan atau permasalahan pemurtadan dan gazw al-Fikr yang dilakukan pihak non-Muslim dan hal ini harus selalu diwaspadai. Dalam konteks gazw al-fikr, terdapat berbagai tuduhan dari pihak luar Islam seperti Islam dikembangkan dengan pedang dan perang, serta tuduhan Islam agama teroris.

${ }^{34}$ Ibnu Hammad, "Kata Pengantar," dalam Syarif Hidayatullah dan Zulfikar S. Dharmawan, Islam Virtual: Keberadaan Dunia Islam di Internet (Jakarta: MIFTA, 2004), h. viii. 
Selain itu, hal yang berulang kali dilakukan oleh pihak non-Muslim di beberapa negara adalah penghinaan terhadap Islam, al-Qur'an dan Nabi Muhammad SAW. Tahun 1988, Salman Rushdie menulis buku The Satanic Verses dan yang paling terakhir adalah Majalah Satiris Charlie Hebdo dari Prancis menerbitkan pula 20 karikatur yang menghina Nabi Muhammad SAW. serta film Innocence of Muslims, yang juga menghina Nabi Muhammad. Film tersebut kemudian diunggah ke jaringan internet yaitu di YouTube dan Google. Akibat dari kehadiran film tersebut, selain melukai hati umat Islam, telah pula menelan korban, antara lain telah menewaskan Dubes Amerika untuk Libya. Dalam kaitan ini, umat Islam perlu memberikan apresiasi kepada Presiden Susilo Bambang Yudhoyono (SBY), dalam pidatonya pada sidang PBB, yang mengatakan bahwa kebebasan berekspresi tidak boleh menghina agama lain dan mengganggu ketenteraman umum. Namun pada acara yang sama, Presiden Amerika Serikat, Barack Husein Obama mengatakan bahwa ia tidak dapat berbuat banyak dalam kasus tersebut. Mereka telah menyalahgunakan kebebasan berekspresi untuk memprovokasi, menghina keyakinan dan melukai hati umat Islam. Semua bentuk serangan terhadap Islam, al-Qur'an dan Nabi Muhammad SAW., mereka selalu berdalih atas kebebasan berekspresi.

Dalam kontek dakwah, semua tuduhan itu harus dijawab secara akademis, bukan dengan sentimen yang berlebihan. Sejauh ini memang sudah ada beberapa upaya untuk melawannya seperti yang dilakukan oleh Irene Handono dan teman-temannya. Ia menulis buku dengan judul Islam Dihujat: Menjawab Buku The Islamic Invasion. ${ }^{35} \mathrm{Ke}$ depan usahausaha seperti itu, harus terus dilakukan, sehingga ada keseimbangan informasi dan wawasan bagi masyarakat dunia.

Tantangan dakwah pada tataran nasional juga sangat beragam. Bangsa Indonesia sekarang sedang melangkah dari kehidupan agraris yang bersahaja kepada kehidupan industri. Proses industrialisasi dan modernisasi, manusia dapat lupa terhadap hakekat hidup dan fungsi ganda yang diembankannya, yaitu sebagai pengabdi kepada Allah (abdun), sebagai khalifah dan penerus risalah kenabian. Manusia dapat menjadi makhluk penyembah teknologi, materi dan kepada sesama. Kalau kondisi ini yang muncul, akibatnya akan menghasilkan industri yang mengelu-elukan teknologi, serta muncul sikap mental arogan terhadap nilainilai transenden yang ditawarkan oleh wahyu Ilahi. Kemudian pada gilirannya akan menjurus kepada pemikiran dan sikap hidup yang sekuler, baik dalam pengertian pemisahan agama dengan politik, maupun dalam pengertian terbebasnya manusia dari kontrol ataupun komitmen terhadap nilai-nilai agama.

Ilmu pengetahuan dan teknologi (IPTEK) sebagai bagian dari kebudayaan, saat

${ }^{35}$ Buku berjudul The Islamic Invasion ditulis oleh Robert Morey, terbitan Christian Scholars Press, Las Vegas. Kesan setelah membaca buku tersebut bahwa penulisnya tidak paham tentang Islam. Ia menghujat Islam, menghujat Allah dan Nabi Muhammad SAW. Buku tersebut telah diterjemahkan dalam berbagai bahasa seperti Prancis, Jerman, Italia dan Belanda. Lihat Irena Handono, et al., Islam Dihujat: Menjawab Buku The Islamic Invasion (Kudus: Bima Rodheta, 2004), h. 6. 
ini tidak seorang pun manusia dapat melepaskan diri dari pengaruh teknologi. Manusia modern yang ditopang oleh kemajuan ilmu pengetahuan dan teknologi (IPTEK) dan masyarakat industri termasuk di dalamnya, sering memperlihatkan ciri sebagai berikut, yaitu individualistik, menonjolnya pertimbangan material, bersifat egois dan rasional serta menonjolnya pertimbangan pragmatis. Ciri dan pola hidup yang demikian, kita akan dapat memahami bagaimana masa depan kemanusiaan, apakah masih dapat mempertahankan martabat kemanusiaan ataukah akan larut dalam arus besar peradaban modern dan industrialisasi. Bila kondisi ini tidak diintervensi oleh agama melalui kegiatan dakwah, maka manusia akan menjadi tawanan dari hasil ciptaannya sendiri dan penyembahan kepada diri sendiri. ${ }^{36}$

Dakwah Islam dituntut untuk memberikan nilai terhadap ilmu pengetahuan, yaitu pada tahap aksiologis, sehingga penerapan ilmu tidak memberikan dampak negatif bagi kehidupan umat manusia. Demikian juga halnya dalam penerapan teknologi. Baik terhadap ilmu pengetahuan maupun terhadap teknologi, yang sangat menentukan disini adalah manusianya yang mengendalikan ilmu dan teknologi itu.

Tantangan berikutnya, yang semakin terasa saat ini adalah akibat dari munculnya era globalisasi. Pada era ini, dunia terasa tidak luas lagi dan kehidupan manusia antar negara menjadi transparan. Akibatnya adalah muncul nilai-nilai baru yang dapat mempengaruhi perilaku dan sikap seseorang. Tarik menarik antara nilai-nilai lama yang bersumber dari agama dengan nilai-nilai baru yang belum tentu sesuai dengan budaya nasional dan ajaran Islam, menuntut kegiatan dakwah yang lebih intens.

Media massa saat ini, yaitu radio, televisi, pers dan teknologi mutakhir, dikuasai oleh pihak Barat. Dalam konteks dakwah keberadaaannya harus selalu diperhitungkan, sebab secara teori media masa mempunyai fungsi memberikan informasi (to inform), mendidik (to educate) dan menghibur (to intertaiment). Media massa juga bersifat ambivalen, pada satu sisi menawarkan "rahmat" yaitu kebaikan, kemudahan dan pencerahan kepada umat manusia sebagaimana fungsi di atas. Namun pada sisi lain atau dalam kenyataannya juga menawarkan "laknat," yaitu mempunyai kekuatan menghancurkan dan merusak. Menurut Akbar S. Ahmed, media Barat sekarang telah mendominasi dan hadir di manamana dengan peranannya yang ikut menstimulasi, merongrong, mempengaruhi, membentuk opini dan menantang umat Islam. ${ }^{37}$ Dampak kehadiran media massa, yang ambivalen menuntut kegiatan dakwah yang mampu mengantisipasi hal itu, sehingga umat memiliki kemampuan untuk mewaspadainya.

\footnotetext{
${ }^{36}$ Kuntowijoyo, Paradigma Islam: Interpretasi Untuk Aksi (Bandung: Mizan, 1991), h. 159.

${ }^{37}$ Akbar S. Ahmed, Posmodernisme: Bahaya dan Tantangan Bagi Islam, terj. M. Sirozi (Bandung: Mizan, 1993), h. 11.
} 


\section{Perumusan Peta Dakwah}

Dakwah adalah kegiatan sosialisasi dan pelembagaan ajaran Islam serta upaya peningkatan dan perbaikan kehidupan umat manusia sesuai dengan tuntutan ajaran Islam, harus ditangani dengan serius dan profesional. Dalam kegiatannya dakwah harus bertitik tolak dari perubahan sosial dan kondisi objektif kehidupan masyarakat atau umat. Untuk memperoleh gambaran yang jelas tentang medan dakwah, maka dapat ditempuh melalui penelitian dan pengkajian ulang terhadap pelaksanaan dan formulasi dakwah yang digunakan dewasa ini. Hal lain yang juga cukup penting melakukan penelitian dakwah secara periodik dan sejatinya sebelum kegiatan dakwah dilakukan, telah ada kejelasan tentang peta dakwah.

Peta dakwah adalah penggambaran secara sistematis dan naratif tentang suatu realitas sosial di tengah-tengah masyarakat, yang akan dijadikan medan dakwah. Penggambaran tersebut meliputi situasi sosial, ekonomi, budaya, dan politik. Kemudian juga menyangkut sumber daya alam (SDA) dan sumber daya manusia (SDM) serta penggambaran skala prioritas masalah dakwah yang perlu segera untuk ditangani. ${ }^{38}$ Kelemahan dakwah selama ini, karena belum adanya peta dakwah yang memberikan gambaran yang objektif terhadap hal-hal yang disebutkan di atas. Disebabkan hal itu kegiatan dakwah sering mengalami benturan-benturan yang pada gilirannya menjadi hambatan bagi kemajuan dakwah Islam.

Selain itu, penelitian dan pemikiran serta gagasan cerdas tidak hanya terfokus pada objek dakwah, tapi harus menyeluruh terhadap sistem dakwah, yaitu dai, mad'uw, materi, metode, media dan organisasi dakwah. Selanjutnya pengelola organisasi dakwah dan dai dituntut untuk memahami secara baik tentang kekuatan, kelemahan, peluang dan tantangan dakwah. Dari pemahaman tersebut akan lahir sikap untuk memanfaatkan kekuatan dan peluang dan dapat menekan dan mengantisipasi terhadap kelemahan dan tantangan.

Dalam menghadapi kemajuan ilmu pengetahuan dan teknologi serta dampak globalisasi, maka pengelola dakwah dan dai harus ada keberanian untuk mengkaji ulang terhadap konsep dan pelaksanaan dakwah dewasa ini. Lebih jauh dari itu, perlu adanya reformulasi terhadap konsep dakwah yang disesuaikan dengan perkembangan ilmu pengetahuan dan teknologi. Jika hal itu tidak dilakukan, maka dakwah akan tertinggal dari kemajuan sosial masyarakat.

\section{Penutup}

Dakwah sebagai kegiatan sosialisasi Islam harus berlangsung secara terus menerus, dari satu generasi kepada negeri berikut, dari zaman ke zaman hingga akhir zaman. Karena

\footnotetext{
${ }^{38}$ Abdul Munir Mulkhan, Paradigma Intelektual Muslim (Yogyakarta: Sipress. 1993), h. 245
} 
itu, dakwah harus dirumuskan dan direncanakan untuk jangka panjang. Dai dan oraganisasi dakwah memegang peranan penting dalam upaya perencanaan, pelaksanaan dan eveluasi serta mengatasi berbagai persoalan dakwah dan persoalan umat semakin komplek di era globalisasi, yang menuntut kegiatan dakwah secara profesional. Kegiatan dakwah harus mempertimbangkan berbagai faktor pendukung dan penghambat serta kemampuan menjadi penyeimbang dalam kehidupan yang terus berubah.

Dalam konteks ini, merumuskan dan menganalisis elemen-elemen yang menjadi kekuatan, kelemahan, peluang dan tantangan dakwah menjadi tugas bersama dai, organisasi dakwah dan lembaga pendidikan yang bergerak dalam bidang dakwah. Hal itu dapat dilakukan dalam skala kecil, mulai dari sebuah desa, kecamatan, propinsi, negara, hingga peta dakwah internasional. Kemudian penggambaran itu harus dituangkan dalam peta dakwah. Berdasarkan peta inilah, dakwah dikemas dalam bentuk silabus, pemilihan metode yang tepat serta penggunaan media yang relevan. Jika langkah-langkah ini dapat dilakukan, maka dakwah akan mampu menjadi penggerak, perubah dan pembumian ajaran Islam untuk menjadi rahmat sejagat.

\section{Pustaka Acuan}

Abdullah. Wawasan Dakwah: Kajian Epistemologi, Konsepsi dan Aplikasi Dakwah. Medan: IAIN Press, 2002.

Ahmed, Akbar S. Posmodernisme: Bahaya dan Tantangan Bagi Islam, terj. M. Sirozi. Bandung: Mizan, 1993.

Al-Faruqi, Ismail R., dan Lois Lamya al-Faruqi. Atlas Budaya: Menjelajah Khazanah Peradaban Gemilang, terj. Ilyas Hasan. Bandung: Mizan, t.t.

Ali, A. Mukti. Beberapa Persoalan Agama Dewasa Ini. Jakarta: Rajawali Pers, 1987.

Arnold, Thomas W. The Preaching of Islam, terj. A. Nawawi Rambe. Jakarta: Wijaya, 1985.

Aziz, Moh Ali. Ilmu Dakwah. Jakarta: Kencana Prenada Media Group, 2004.

Badan Pusat Statistik. Penduduk Indonesia 2010.

Fatah, Eep Saefulloh. "Kalangan Islam: dari Statistik ke Politik?," dalam Dhurorudin Mashad (ed.). Akar Konflik Politik Islam di Indonesia. Jakarta: Pustaka Al-Kautsar, 2008.

Hasan, Sahal L. et al., (ed.). Memilih Partai Islam. Jakarta: Gema Insani Press, 1998.

Hamka. Prinsip dan Kebijaksanaan Dakwah Islam. Jakarta: Pustaka Panjimas, 1981.

Hamka. Sejarah Umat Islam. Singapura: Pustaka Nasional, 2005.

Hajjâj, Muslîm bin. Shaḥ̂̂h al-Muslîm, Vol. I, Bab Îmân. No. 78.

Hubeis, Musa, dan Mukhamad Najib. Manajemen Strategik dalam Pengembangan Daya Saing Organisasi. Jakarta: Elex Media Komputindo, 2008.

Handono, Irena, et al. Islam Dihujat: Menjawab Buku The Islamic Invasion. Kudus: Bima Rodheta, 2004. 
MIQOT Vol. XXXVI No. 2 Juli-Desember 2012

Ibnu Hammad. "Kata Pengantar," dalam Syarif Hidayatullah dan Zulfikar S. Dharmawan. Islam Virtual: Keberadaan Dunia Islam di Internet. Jakarta: MIFTA, 2004.

Jurdi, Syarifuddin. 1 Abad Muhammadiyah. Jakarta: Kompas Media Nusantara, t.t.

Kuntowijoyo. Paradigma Islam: Interpretasi Untuk Aksi. Bandung: Mizan, 1991.

Maarif, Ahmad Syafii. Islam dalam Bingkai Keindonesiaan dan Kemanusiaan: Sebuah Refleksi Sejarah. Bandung: Mizan, 2009.

Masy’ari, Anwar. Butir-Butir Problematika Dakwah. Surabaya: Bina Ilmu, 1993.

Mahmud, Ali Abdul Halim. Dakwah Fardiyah, terj. As‘ad Yasin. Jakarta: Gema Insani Press. 1995.

Madjid, Nurcholish. Islam Doktrin dan Peradaban. Jakarta: Yayasan Wakaf Paramadina, 1992.

Mulkhan, Abdul Munir. Paradigma Intelektual Muslim. Yogyakarta: Sipress. 1993.

Natsir, M. Fiqhud Dakwah. Jakarta: Media Dakwah, t.t.

Noer, Deliar. "Kata Pengantar," dalam Khamami Zada, Islam Radikal. Jakarta: Teraju, 2002.

Quthb, Sayyid. Fî Zhilâl al-Qur'ân, Vol. I. Beirut: Dâr al-Syurûq, 1986.

Rais, M. Amien. Cakrawala Islam. Bandung: Mizan, 1991.

Sukrianto, et al. Pergumulan Pemikiran dalam Muhammadiyah. Yogyakarta: Sipress, 1990.

Taher, Tarmizi. Menuju Ummatan Wasathan. Jakarta: PPIM-IAIN, 1998.

Thaba, Abdul Aziz. Islam dan Negara dalam Politik Orde Baru. Jakarta: Gema Insani Press, 1996.

Tarigan, Azhari Akmal. Jalan Ketiga Pemikiran Islam HMI. Bandung: Citapustaka Media Perintis, 2008.

Zada, Khamami. Islam Radikal. Jakarta: Teraju, 2002. 